\title{
EFFECT OF LIPOPOLYSACCHARIDE AND THE AMELIORATIVE EFFECT OF THE ANTIOXIDANT MELATONIN ON SOME PHYSIOLOGICAL PARAMETERS OF SHEEP EMBRYOS
}

DIAA FARRAG IBRAHIM AHMED, SAMIR ATTIA ZAAHKOUK, EL YAMANI IBRAHIM EL ZWAHRY

Department of Zoology - faculty of science - Al Azhar university

Email: elharamain3@gmail.com

\section{Abstract}

As known, lipopolysaccharide (LPS) is a toxin that is secreted from gram negative bacteria as $E$. coli which is present in the gut of animals like sheep and it may be transported to the embryo through the blood affect the brain and other organs. Little is known about the effect of LPS on liver and kidney function or hematological parameters. In the present study we found that melatonin treatment improved most of the liver functions that affected by LPS injection and also improve kidney function, although LPS injection was found to lead to a decrease of createnine, urea and uric acid for unknown reason. concurrently injection of melatonin plus LPS led to decreasing most of blood indices while increasing of RBCs count and WBCs count. So, we concluded that usage of melatonin as general antioxidant is useful against LPS toxicity.

Key words: LPS - Ameliorative - Melatonin- Kidney - Liver - Blood

\section{Introduction}

A growing number of studies indicate that maternal infection during pregnancy is associated with adverse fetal development and neonatal health . These studies revealed that maternal endotoxin treatment during late gestation altered the female febrile and male and female cortisol response to endotoxin exposure later in life; however, the response was dependent on the endotoxin treatment regime that the pregnant sheep received, Fisher et al. (2010). At the heighst concentration of LPS, significantly decreased fluidity of membrane lipids was observed, Gwozdzinsk $\boldsymbol{e t}$ al. (2003).

Yates et al. ( 2011) reported that bacterial lipopolysaccharide endotoxins (LPS) elicit inflammatory responses reflective of acute bacterial infection. Total white blood cell concentrations were not affected $(P \geq 0.135)$ by LPS, but neutrophil and monocyte fractions of white blood cells were increased $(P \leq 0.047)$ by LPS at 12 and $24 \mathrm{~h}$ and at $24 \mathrm{~h}$ after bolus, respectively, and lymphocyte fraction was increased $(P=0.037)$ at $2 \mathrm{~h}$ and decreased $(P \leq 0.006)$ at 12 and $24 \mathrm{~h}$ after bolus. Red blood cell and hemoglobin concentrations and hematocrit $(\%)$ were elevated $(P \leq 0.022)$ by LPS at 2 and $4 \mathrm{~h}$ after bolus.

In controls, LPS caused severe liver injury, as indicated by increased liver enzyme levels and apoptotic cell death. This was associated with distinct sinusoidal 
perfusion failure and microvascular intrahepatic leukocyte accumulation, Roller $\boldsymbol{e t}$ al. (2010).

Kirsten et al. (2010) stated that prenatal lipopolysaccharide (LPS) exposure causes reproductive, behavioral and neurochemical injuries in both the mother and pups. Prenatal LPS administration (100 micro g/ kg,i.p.) on gestational day 9.5 impaired the male offspring's social behavior in infancy and adulthood. Prenatal LPS exposure disrupted the dopaminergic system involved with motor function, but this neurochemical effect was not accompanied by behavioral impairment probably due to adaptive plasticity processes. Not with standing behavioral impairment was revealed when enhanced were challenged with LPS, resulting in enhanced sickness behavior.

Tarawaki et al. (2010) hypothesized that a very low level of plasma endotoxin (LPS)contributes to chronic inflammation in advanced chronic kidney disease patients. He revealed a significant relationship between LPS and C-reactive protein suggested that very low grade endotoxemia is contributing to systemic inflammation in hemodialysis patients.

Lipopolysaccharide (LPS) plays a critical role in the pathogenesis of sepsis due to gram-negative bacterial infections, therefore, LPS-neutralizing molecules could have important clinical application, Ren et al. (2010).

Brendt et al. (2009) recorded that on day 14 the red blood cell count and hemoglobin concentration had increased by approximately $10 \%$ from baseline in the darbepoetin alfa (DA) group but had decreased after LPS on day 3 and 14 and in animals administered LPS/darbepoetin alpha. LPS abolishes erythropoiesis and iron use evoked by DA and this is accompanied by a decrease in hemoglobin concentration and red blood cell concentration accordingly, endotoxin suppresses DA ability to increase erythropoiesis.

LPS vehicle mice displayed multiorgan dysfunction as evidence by elevated plasma urea and creatinine (kidney) aspartate aminotransferase (AST) and alanine aminotransferase (ALT; liver) and lactate dehydrogenase (LDH) and reduced ejection fraction (heart), Wang et al. (2010). When incubating blood of leukocytes with LPS the elasticity moduli of erethrocytes did not change, Bellary et al. (1995).

An enormous amount of data has been published in recent years demonstrating melatonin's defensive role against toxic free radicals Giyasettin et al.(2001). Besides its effect on the reproductive system, recent findings suggest that melatonin may have effects on ageing and inhibition of oxidant stress, Reiter et al. (1996) and Reiter (1995). Recent studies demonstrated that melatonin is an antioxidant which 
scavenges hydroxyl radicals generated in vitro by hydrogen peroxide exposed to ultraviolet light Reiter et al. (1999) and Ustundag et al. (1999).

Hardeland et al. (1993) investigated that melatonin is secreted during the darck period after exposure to constant light for along time, melatonin secration decreases to a minimum level a long with a decrease in pineal gland weight . in the presence of oxygen , the durenal rhythmicity of light and darkness causes a cycle of enormous amplitude in the concentration of reactive oxygen species.

Recently, it has been demonstrated that exogenous melatonin administration causes a two-fold increase in GSH-PX activity within $30 \mathrm{~min}$ in the brain of the rat, Barlow-Walden et al. (1996). Melatonin, N-acetyle-5-methoxytryptamine, is a ubiquitous molecule with many different functions. Initially, it has been involved in the neuroendocrine system, mainly in the reproductive physiology, Reiter (1973). A good antioxidant must fulfil a series of characteristics : large distribution within tissues, cells and subcellular compartments, ability to cross morphophysiologic barriers and quick transport into the cells, Karbownik and Reiter (2000). Physical chemistry properties of melatonin allow this molecule to penetrate into all cells and cellular compartments in the organism, since it is highly soluble in lipids and partially in water, Ceraulo et al. (1999) and Leon et al. (2004).

\section{Aim of the work:-}

The aim of this study is to evaluate the harmful effects of lipopolysaccharide and ameliorative effect of melatonin on the blood ,liver and kidney of sheep fetus.

\section{Materials and methods:}

Six sheep were prepared for experiment all of them are pregnant $70 \%$ of gestation. Animal were kept them in cages with free food and water, then after 70 percent of gestation control mother(two animals) was injected intravenously with saline solution. The second group( two animals) injected intravenously with LPS (100 ng/kg of the mother weight), Mallard et al. (2003) and for the third group(two animals) was injected intraperitoneally with melatonin $(5 \mathrm{mg} / \mathrm{kg}$ of the mother weight), Rao and chhuncha (2009) two dayes after melatonin injection we inject LPS $100 \mathrm{ng} / \mathrm{kg}$ of the mother weight. Each group left three days after injection of LPS then sacrificed. After three days we sacrifice animals and take the embryos out of the mother and collect little of blood from them on anticoagulant for complete blood picture, and on another test tube we take little of blood without anticoagulant for the other blood chemistry. 
Hematological parameters in embryos:

\section{Determination of hemoglobin concentration:}

Hemoglobin concentrations were measured using bioadwic kits, according to the method cited by Drabkin and Austin (1932).

This technique based on conversion of hemoglobin into red cyanomethoglobin under the influence of potassium ferricyanide and potassium cyanide. The color intensity of result chromogen indicates hemoglobin concentration.

Determination of hematocrit value (PCV):-

It was estimated according to the method of Rodak (1995) using heparinized capillary tube.

Counting of both red, white blood cells and erythrocyte indices:-

These had done according to the method of Rodak (1995) using hemocytometer.

For RBCs. Count and WBCs count.

\section{Calculation of differential leukocyte count:-}

According to Rodak (1995), the differential leukocyte counts were achieved using Leishman's stain to contrast between types and percentage of each type of WBCs.

Colorimetric measurement of serum glutamic oxaloacetic transaminase SGOT (AST) and serum glutamic pyruvic transaminase SGPT (ALT) in serum activity:-

Serum AST and ALT is determined spectrophotometrically using (Bio-Adwic) kits according to Reitman and Frankel (1957).

Measurement of serum alkaline phosphatase activity:-

Alkaline phosphatase was determined using kit of Bioadwic and the method of John (1982).

Assessment of acid phosphatase activity:-

Acid phosphatase activity were determined according to Andersch and Szczypinski (1947) method using Bio-adwic kit.

Determination of serum total protein level:-

Serum total proteins were colorimetrically measured according to the method of Doumas (1975), using Bio-Adwic kit. 


\section{Estimation of serum albumin level:-}

Serum albumin was measured using bromocresol-green (BCG) method according to the method of Doumas (1971) using the kits of centronic GmbHGermany.

\section{Colorimetric determination of serum total bilirubin concentration:-}

Serum bilirubin was measured using Bio-Adwic kit and method of Wooton (1964).

\section{Kidney function tests:-}

\section{Enzymztic determination of serum urea concentration :-}

Serum urea estimated according to the colorimetric method described by Patton and Crouh (1977) using the kits of Bio-Adwic.

\section{Enzymatic assessment of serum uric acid level:-}

Serum uric acid colorimetrically measured according to the method of Fossati et al. (1980).

\section{Colorimetric determination of createnine concentration :-}

Createnine were measured using spectrophotometer according to Bartels et al. (1972), using Bio-Adwic kit.

\section{Statistical analysis:}

Data statistically analysed using Mean \pm standard error and T-test assuming unequal variances at different probability by Exel program of Microsoft office 2003 .

Results :

\section{Liver function tests}

As in table (1) data analysis showed significant decrease in ALT in serum of sheep embryo in group treated with both melatonin and lipopolysaccharide together. At the same time there is a significant increase in serum AST in LPS treated group but data shows significant decrease in AST in serum of melatonin + LPS group.

The study of effect of LPS and melatonin on sheep embryo showed significant decrease in total bilirubin in group that treated with melatonin + Lipopolysaccharide but measuring effect of Lipopolysaccharide on direct bilirubin data showed significant decrease as in table (1).

As in table (1) Albumin decreased significantly in both groups, LPS treated and M+LPS groups. Also, alkaline phosphatase shows significant decrease in LPS group and M+ LPS group as indicated in table (1) and figure (6). 


\section{Kidney function tests:-}

The study showed significant decrease in each of the following parameters creatinine, urea and uric acid in all treated groups as recorded in table (2).

\section{Hematological parameters:-}

Melatonin and LPS treatment lead to significant increase of RBCs count as in table (3).

Data revealed that LPS and M+LPS treatment on WBCs count showed significant decrease of WBCs count in LPS group but significantly increased in M+LPS group as in table (3).

\section{Blood indices:-}

Data show significant increase in haematocrite value in LPS treated group. In case of MCV and MCH the results show significant decrease in M+LPS treated group, as in table (4).

\section{Differential leukocyte count:-}

Lipopolysaccharide lead to significantly increase in granulocytes but in group that treated with melatonin + Lipopolysaccharide data show significant decrease. By studying effect of melatonin + Lipopolysaccharide treatment on sheep embryo monocytes, results showed significant increase, as in table (5).

Table (1): Effect of LPS and M+ LPS on Liver function tests of sheep embryos

\begin{tabular}{|l|c|c|c|}
\hline \multicolumn{1}{|c|}{ parameter } & control & LPS & M + LPS \\
\hline GPT (U/ml) & $5.23 \pm 0.015$ & $5.05 \pm 0.05$ & $1.45 \pm 0.15^{*}$ \\
\hline GOT (U/ml) & $10.23 \pm 0.23$ & $52.19 \pm 0.19 *$ & $4.02 \pm 0.02^{*}$ \\
\hline Total bilirubin (mg/dl) & $0.22 \pm 0.015$ & $0.165 \pm 0.015$ & $0.115 \pm 0.015^{*}$ \\
\hline Direct bilirubin (mg/dl) & $0.12 \pm 0.02$ & $0.045 \pm 0.015^{*}$ & $0.03 \pm 0.01$ \\
\hline Albumin (g/dl) & $2.43 \pm 0.03$ & $0.99 \pm 0.01^{*}$ & $0.43 \pm 0.025^{*}$ \\
\hline ALP (U/L) & $1.83 \pm 0.025$ & $0.708 \pm 0.008^{*}$ & $1.64 \pm 0.04^{*}$ \\
\hline$*=\mathrm{P}<0.05$ at one tail & & & \\
\hline
\end{tabular}

Table (2): Effect of LPS and M+ LPS on kidney function tests of sheep embryos

\begin{tabular}{|l|c|c|c|}
\hline \multicolumn{1}{|c|}{ parameter } & control & LPS & M+LPS \\
\hline Createnin (mg/dl) & $1.42 \pm 0.02$ & $0.39 \pm 0.01^{*}$ & $0.17 \pm 0.03^{*}$ \\
\hline Urea (mg/dl) & $28 \pm 1.00$ & $19 \pm 1.00^{*}$ & $16.13 \pm 0.13^{*}$ \\
\hline Uric acid (mg/dl) & $2.23 \pm 0.03$ & $1.715 \pm 0.015^{*}$ & $1.95 \pm 0.05^{*}$ \\
\hline
\end{tabular}

$*=\mathrm{P}<0.05$ at one tail 
Table (3): Effect of LPS and M+LPS on hematological parameters in sheep embryos

\begin{tabular}{|l|c|c|c|}
\hline \multicolumn{1}{|c|}{ parameter } & control & LPS & M + LPS \\
\hline RBCs count $\mathrm{X} 10^{6}$ & $3.1 \pm 0.1$ & $3.2 \pm 0.1$ & $6.665 \pm 0.17^{*}$ \\
\hline Platelets count X10 & $153 \pm 3.00$ & $164 \pm 1$ & $159 \pm 1.00$ \\
\hline WBCs count X10 & $2250 \pm 50.00$ & $1625 \pm 25^{*}$ & $2950 \pm 50^{*}$ \\
\hline Hemoglobin & $9.2 \pm 0.1$ & $9.5 \pm 0.1$ & $9.3 \pm 0.100$ \\
\hline HCT & $27.15 \pm 0.15$ & $28.3 \pm 0.1^{*}$ & $27.4 \pm 0.1$ \\
\hline
\end{tabular}

Table (4): Effect of LPS and M + LPS on blood indices parameters in sheep embryos

\begin{tabular}{|c|c|c|c|}
\hline parameter & control & LPS & M+LPS \\
\hline MCV $\left(\mu^{3)}\right.$ & $88.1 \pm 0.1$ & $88.5 \pm 0.1$ & $40.1 \pm 0.1^{*}$ \\
\hline MCH $(\mathrm{Pg})$ & $29.5 \pm 0.1$ & $29.5 \pm 0.1$ & $13.75 \pm 0.25^{*}$ \\
\hline MCHC $(\mathrm{gm} / 100 \mathrm{ml})$ & $33.15 \pm 0.15$ & $33.15 \pm 0.15$ & $33.85 \pm 0.16^{*}$ \\
\hline
\end{tabular}

Table (5): Effect of LPS and M+LPS on differential leukocyte count in sheep embryos Differential leukocyte count

\begin{tabular}{|c|c|c|c|}
\hline parameter & control & LPS & M+LPS \\
\hline Granulocytes \% & $33.5 \pm 1.5$ & $82.5 \pm 2.5^{*}$ & $16 \pm 1.00^{*}$ \\
\hline Lymphocytes \% & $62.5 \pm 2.5$ & $19.5 \pm 0.5$ & $69.5 \pm 0.5$ \\
\hline Monocytes \% & $3.5 \pm 0.5$ & $1.5 \pm 0.5$ & $17 \pm 1.00^{*}$ \\
\hline
\end{tabular}

$$
*=\mathrm{P}<0.05 \text { at one tail }
$$

\section{Discussion:}

This study was achived to detect effect of lipopolysaccharide and melatonin on liver function tests, kidney function tests and some haematological parameters haematology. The results show a significant decrease in ALT and AST level in M+LPS group as compared with control, this is may be due to ameliorative effect of melatonin and may be due to the antioxidant property for melatonin but data shows a significant decrease in GOT in LPS group this is may be due to the distructive effect of LPS on liver cells.

Total bilirubin decreased in group treated with melatonin + Lipopolysaccharide this is propably due to effect of melatonin which capture the free radicals and the harmful substances that formed by LPS. Melatonin injection caused a decrease in lipid peroxidation especially in brain . in addition, melatonin application resulted in increased GSH-PX activity , which has an antioxidant effect. Thus , melatonin is not only a direct scavenger of toxic radicals, but also stimulates the antioxidative 
enzyme GSH-PX activity to detoxify hydroxyl radical produced by constant light exposure, Giyasttin et al. (2001).

In the last decade the molecule of pineal origin, melatonin, has attracted the researchers attention due to its antioxidant ability, since it is able to scavenge free radicals and to increase activity and expression of the main antioxidant enzymes. Melatonin is a powerful free radical scavenger. It is able remove $\mathrm{H}_{2} \mathrm{O}_{2} ; \mathrm{oH}$, peroxinitrite anion (oNoo') singlet oxygen $\left({ }^{1} \mathrm{O}_{2}\right), \mathrm{O}^{-}{ }_{2}$ and peroxyl radical (LOO). Melatonin antioxidant mechanism differs from mechanisms followed by the other antioxidants, since all of them need a redox cycle after electron donation. Thus , classic antioxidants are able to promote oxidation as well as to prevent it. However, melatonin, as an electron-rich molecule, is able to interact with free radicals through consecutive reactions giving rise to many stable compounds that can be excreted by urine.

The decreasing in the levels of kidney function tests in M+LPS group may be due to improving of kidney nephrons by action of melatonin which has free radicals scavenger properity. On the other hand, the large subcellular distribution of melatonin allows its interaction with almost any kind of molecule, diminishing oxidative damage in both lipid and aqueous environments. This is supported experimentally by numerous data that show that melatonin is able to protect lipids in the cellular membranes, proteins in the cytosol and DNA in the nucleus from free radical damage, Reiter et al. (2004).

Uchida et al. (1999) investigated that tissue lipid peroxidation (LPO) is a degradative phenomenon as a consequence of free radical chain production and propagation which affects mainly to polyunsaturated fatty acids and that is strongly implied in the pathogenesis of several diseases, such as arteriosclerosis, diabetes, cancer and rheumathoid arthritis, as well as toxicity associated to drugs and aging. In fact the melatonin antioxidant mechanism implied a free radical scavengers cascade, since secondary, and even tertiary, metabolites are also efficient free radicals scavengers, like $\mathrm{N}$-acetyle-N-formyl-5-methoxy kynuramine (AFMK) and N-acetyl-Methoxy kynuramine (AMK), Tan et al. 2001 and Hardeland and Pandi-Perumal (2005).

The formation of such metabolites from melatonin implies that, unlike classic antioxidants, melatonin does not produce prooxidant reactions, Reiter et al. 1998 and Abudu et al. (2004).

The increasing of RBCs count may be due to effect of melatonin on erythropoietin hormone which affects on bone marrow to increase production of red blood corpuscles. On other hand, Mamdouh et al. (1998) reported that Melatonin, the major hormonal product of the pineal gland, is supposed to have both 
chemoprotective and myelostimulatory effects. When melatonin was injected along with aracytin, it would significantly increase $(P<0.05)$ RBC count and $(P<0.01)$ blood platelet count. Injection of melatonin after aracytin treatment would significantly increase $(P<0.01)$ RBC, total leucocytic and platelet counts in comparison with rats treated with aracytin only. These results indicate that melatonin protects bone marrow, lymphoid tissues from damaging effect of cytotoxic drugs, as well as stimulating the suppressed bone marrow.

LPS may decrease immunity because we recorded a significant decrease in WBCs count in LPS injected group, at the same time injection of melatonin with LPS increase immunity by increasing WBCs count. With respect to melatonin, Young-ok et al. (2000) suggested that immunotoxicity induced by lead $[\mathrm{Pb}$, as $\mathrm{Pb}\left(\mathrm{NO}_{3}\right)_{2}$ ] was significantly restored or prevented by melatonin (MLT).

In case of MCV and MCH it decreased significantly when embryos affected with melatonin+LPS this is may be due to effect of the combination between melatonin and Lipopolysaccharide on haem and globin formation. Lipopolysaccharide may be affect on stem cells in bone marrow that responsible for granulocytes production, so, LPS may be lead to activation of stem cells division (abnormally). Injection of melatonin after LPS injection leads to inhibition in granulocyte production.

\section{Conclusion}

At the end we concluded that melatonin has ameliorative effect as antioxidant on liver, kidney functions and blood of animals affected by LPS so, we recommended with melatonin usage in LPS infection.

\section{References:-}

1. Abudu, N.; Miller, J.J.; Attaelmannan, M. and Levison, S.S. (2004) : Vitamins in humann arteriosclerosis with emphasis on vitamin C and vitamin E". Clin Chim Acta ; 339:11-25.

2. Andersch, A.M. and Szczypinski, A.J. (1947):"Use of P-nitrophenylphosphate as the substrate in determination of serum acid phosphatase".

3. Barlow-Walden, L.R.; Reiter, R.J.; Abe, M. et al. (1995):" Melatonin stimulates brain glutathione peroxidase activity". Neurochem Internat ; 26: 497-502.

4. Bartels, H.; Bohmer, M.; and Heierli, C. (1972): "Serum Kreatinbestimmung ohne enteiweissen" Clin. Chim. Acta, 37: 193-197.

5. Bellary, S.; Arden, W.W.; Schwartz, R.W. and Anderson, K.W. (1995):"Effect of lipopolysaccharide, leukocytes, and monoclonal anti-lipid a antibodies on erythrocyte membrane elastance ". Shock.3(2):132-6 .

6. Brendt, P.; Horwat, A.; Schafer, S.T.; Dreyer, S.C.; Gothert, J. and Peters, J. (2009): "Lipopolysaccharide evokes resistance to erythropoiesis induced by the long-acting erythropoiesis induced by the long-acting erythropoietin analogue darbepoetin alpha in rats". Anesth. Analg . 109(3):705-11. . 
7. Ceraulo, L.; Ferrugia, M.; Tesoriere, L.; segreto, S.; Livrea, M.A. and Turco, L. V. (1999):" interactionsof melatonin with membrane models: portioning of melatonin in AOT and Lecithin reversed micelles". J pineal Res;26:108-12.

8. Doumas, B.T. (1975):"Standards for total serum protein assays a collaborative study".Clin. Chem. 21(8): 1159-1166.

9. Doumas, B.T.; Watson, W.A.; and Biggs, H.G. (1971): "Albumin standards and measurements of serum albumin with bromocresol green" clin. Chem. Act. 31:87-96

10. Drabkin, D.L. and Austin, J.H. (1932):"Spectrophotometric studies; spectrophotometric constants for common hemoglobin derivatives in human, dog, and rabbit".J. Biol. Chem., 98:719-725.

11. Fisher, R.E.; Karrow, N.A.; Quinton, M.; Finegan, E.J .; Miller, S.P.; Atkinson, J.L. and Boemans, H.J. (2010):"Endotoxin exposure during late pregnancy alters ovine offspring febrile and hypothalamic-pituitary-adrenal axis responsiveness later in life". Stress. 13(4):334-42.

12. Fossati, P.; Prencipe, L. and Berti, G. (1980):"Use of 3,5-dichloro-2-hydroxy benzenesulfonic acid/4-aminophena zone chromogenic system in direct enzymatic assay of uric acid in serum and urine".Clin. Chem. 26(2): 227-231.

13. Giyasettin, B.; Ergul, E.; Hali, T. C.; Emir, D. and Ali, A. (2001): "Effect of melatonin on oxidative status of rat brain, liver and kidney tissues under constant light exposure" Cell Biochem Funct. 19:37-41.

14. GwoZdzinsk, K.; Pieniazek, A.and Kaca, W.(2003): "Lipopolysaccharide from Proteus mirabilis O29 induced changes in red blood cell membrane lipids and proteins". Int. J. Biochem. cell Biol.; 35(3):333-8.

15. Hardeland, R. and Pandi-perumal, S.R. (2005):" Melatonin,a potent agent in antioxidative defense: actions as a natural food constituent , gastrointestinal Factor,drug and prodrug". Nutr. Metab. (lond),2:22.

16. Hardeland, R.; Poeggeler, B., Balzer, I. and Behrmann, G. (1993):" A hypothesis on the evolutionary origins of photoperiodism based on circadian rhythmicity of melatonin in phylogenetically distant organism. In chronobiology and chronomedicine (Guttenbrunner C, Hidebrandt G, Moog R, (eds)". Peter long verlag: Frankfurt M, ;113-120.

17. John, D.B. (1982):"Clinical laboratory methods".C.V. Mosby Co., USA, ${ }^{\text {th }}$ Ed, P: 580581.

18. Karbownik, M. and Reiter, R.J. (2000):"Antioxidative effects of melatonin in protection againest cellular damage caused by ionizing radiation". Proc Soc Exp Biol Med, 225 : 9-22.

19. Kirsten, T.B.; Taricano, M.; Flõrio, J.C.; Palermo, N. and Bernardi, M.M. (2010): "Prenatal lipopolysaccharide reduces motor activity after an immune challenge in adult male offspring". Behav. Brain Res. 211(1):77-82.

20. Leon, J.; Acuña-Castroviejo, D.; Sainz, R.M.; Mago, J.C.; Tan, D.X. and Reiter, R.J. (2004):" Melatonin and mitochondrial function". Life Sci. 75: 765-790. 
21. Mallard, C.; Welin, A.K.; Peebles, D.; Hagberg, H. and Kjellmer, I. (2003): "White matter injury following systemic endotoxemia or asphyxiain the fetal sheep." Neurochem Res. 28 (2): 215-23.

22. Mamdouh, M. A.; Hussein, A. M. and Arafat, S. S. (1998):"Potential protective effects of melatonin on bone marrow of rats exposed to cytotoxic drugs". comparative biochemistry and physiology Part A : Molecular \&integrative physiology 119,2, 493-501.

23. Patton, C.J. and Crouh, S.R. (1977):"Urea colorimetric end point determination ureaseberthelot reaction ".Annal. Chem. 49: 464-469.

24. Rao, M.V. and Chhuncha, B. (2009): "Protective role of melatonin against the mercury induced oxidative stress in the rat thyroid." Food Chem. Toxicol.

25. Reiter, R.J. (1973): Comparative physiology : pineal gland Annu Rev physiol; 35 : 305328.

26. Reiter, R.J. (1995):" oxidative processes and antioxidative defense mechanisms in the aging brain".FASEB J. 9:526-533.

27. Reiter, R.J.; Guerrero, J.M.; Carcia, J.J. and Acuña-Castroviejo, D. (1998):"Reactive oxygen intermediates, molecular damage, and aging.Relation to melatonin". Ann NY Acad. Sci. 854:410-24.

28. Reiter, R.J.; Pablos, M.I., Agapito, T.T. and Guerrero, J.M. (1996): "Melatonin in the context of the free radical theory of aging". Ann NY Acad. Sci. 786:362-378.

29. Reiter, R.J.; Tan, D.X.; Cabrera, J. et al. (1999):" The oxidant $\backslash$ antioxidant network: role of melatonin". Biol Sig. Recept. 8:56-63.

30. Reiter, R.J.; Tan, D.X.; Gitto, E.; et al. (2004) :"Pharmacological utility of melatonin in reducing oxidative cellular and molecular damage." Pol. J. Pharmacol. 56 (2): 159-70.

31. Reitman, S. and Frankel, S.(1957):"A colotimetric method for determination of serum glutamicoxaloacetic and glutamic pyruvic transaminases".Am. J. Clin. Path. 28:26-63.

32. Ren, W.Y.; Zhu, L.;Hua, F.; Jin, J.J. and Cai, y.y.(2010):"The effect of lipopolysaccharide on gene expression of TLR4 and MD-2 in rat alveolar macrophage and its secretion of inflammation cytokines". Zhonghua Jie He He Hu Xi Za Zhi. 33(5): 36771. Chinese

33. Rodak, L.C. (1995):"Diagnostic Hematology". W.B. Sunders Company, Philadelphia, London-Toronto

34. Roller, J.; Laschke, M.W.; Scheuer, C. and Menger, M.D. (2010).: "Heme oxygenase(Ho) $)^{-1}$ protects from lipopolysaccharide (LPS)- mediated liver injury by inhibition of hepatic leukocyte accumulation and improvement of microvascular perfusion". Langenbecks Arch. Surg. 395(4):387-94.

35. Tan, D.X.; Manchester, L.C.; Burkhardt, S. et al. (2001):" N1-acetyl-N2-Formyl-5methoxykynuramine, a biogenic amine and melatonin metabolite, Functions as a potent antioxidant".FASEB J. 15: 2294-96. 
36. Terawaki, H.; Yokoyama, K.; Yamada, Y.; Maruyama, Y.; Lida, R.; Hanaoka, K.; Yamamoto, H.; Obata, T. and Hosoya, T. (2010): "Low grade endotoxemia contributes to chronic inflammation in hemodialysis patients: examination with novel lipopolysaccharide detection method". Ther. Apher. Dial. 14 (5):477-82.

37. Uchida, K.; Shiraishi, M.; Naito, Y.; Torii, Y.; Nakamura, Y. and Osawa, T. (1999):"Activation of stress signaling pathways by the end product of lipid peroxidation 4-hydroxy-2-nonenal is a potential inducer of intracellular peroxide production". J Biol Chem. 274: 2234-42.

38. Ustundağ, B.; Canatan, H. and Mlatoni (1999):" Apotent antioxidant and free radical scavenger (in Turkish)".Firat Tip Dergisi (FiratMed );1:502-512.

39. Wang, H.; Liu, H.; Jia, Z.; Olsen, C.; Litwin, S.; Guan, G. and Yang, T. (2010).: "Nitro-oleic acid protects against endotoxin-induced endotoxemia and multiorgan injury in mice". Am. J. Physiol. Renal. Physiol .298(3):F 754-62.

40. Wooton, I. D. P. (1964):"Micro-analysis in medical biochemistry $4^{\text {th }}$ Ed., London. P: 82".

41. Yates, D. T.; Löest, C. A.; Ross, T. T.; Hallford, D. M.; Carter, B. H. and Limesand, S. W. (2011):: "Effects of bacterial lipopolysaccharide injection on white blood cell counts, hematological parameters, and serum glucose, insulin, and cortisol concentrations in ewes fed low- or high-protein diets" J. Anim. Scie. 2011-3969.

42. Young-Ok, K.; Myoung-Yun, P. and Joung-Hoon, K. (2000):"Influence of melatonin on immunotoxicity of lead". International Journal of immunopharmacology. 22,10,821832.

\section{تأثير الليبوبولى سكريد والتأثير المحسن لمصناد

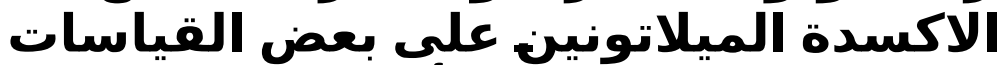 الفسيولوجية لأجنة الغنم}

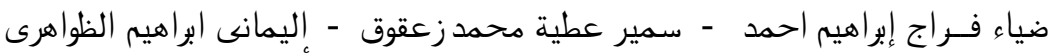

$$
\begin{aligned}
& \text { قسم علم الحيوان كلية العلوم جامعة الأزهر اليماني } \\
& \text { البريد الإلكترونى : elharamain3@gmail.com }
\end{aligned}
$$

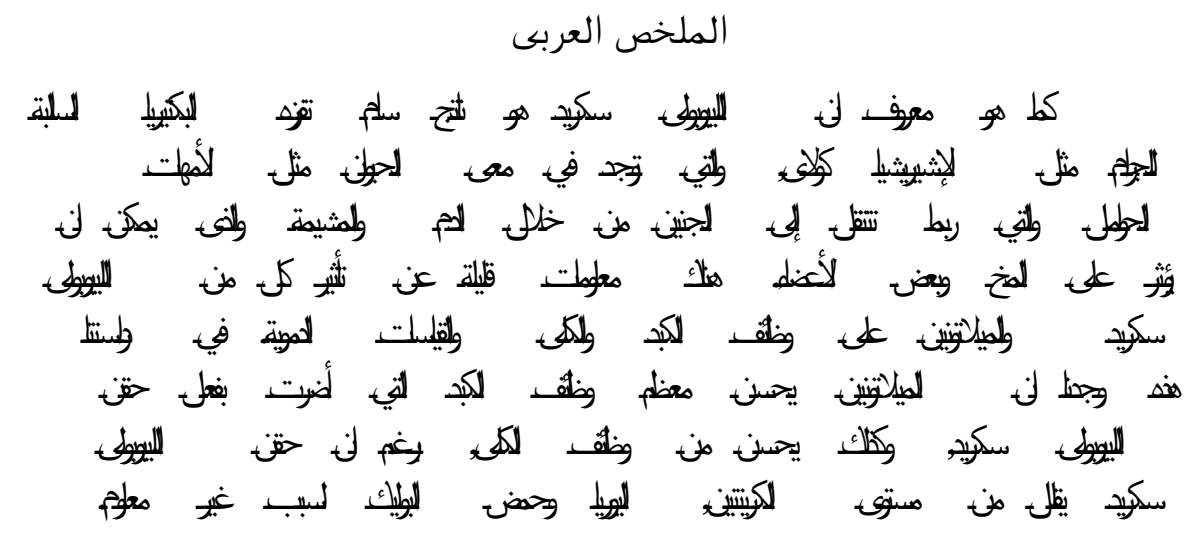


EFFECT OF LIPOPOLYSACCHARIDE AND THE AMELIORATIVE .......13

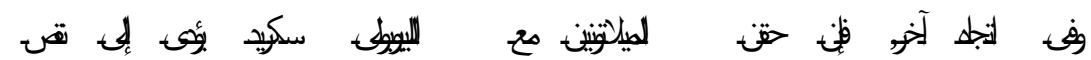

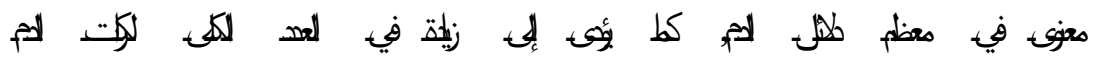

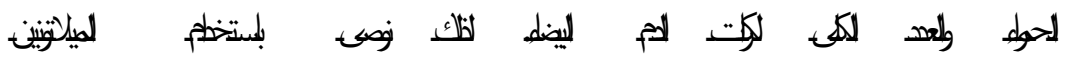

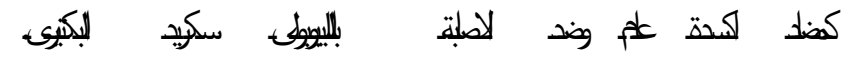

